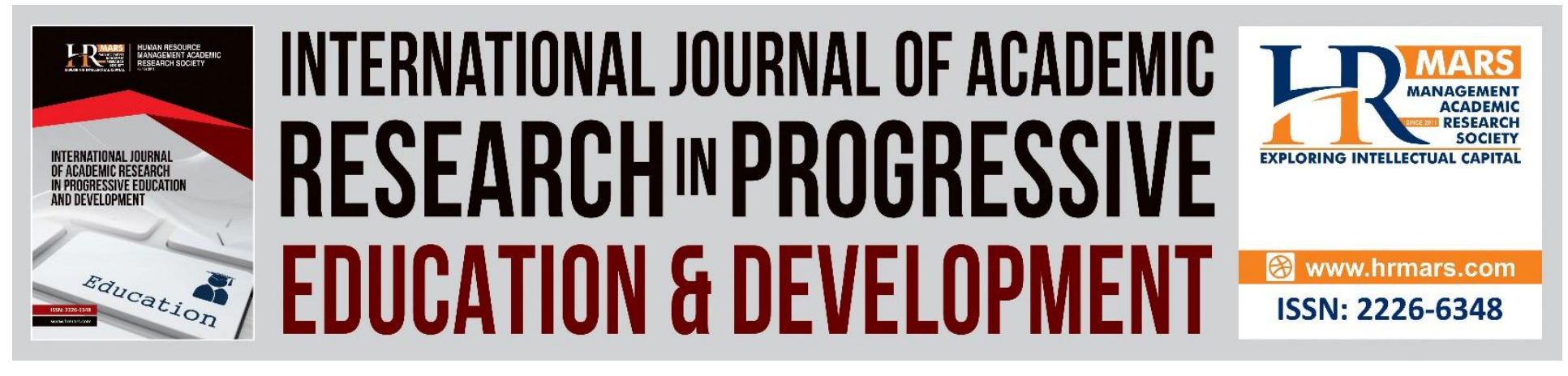

\title{
Investigating Mastery Level of Arabic Academic Vocabulary (AAV): A Study Among Malaysian Public Universities
}

Mohamad Nor Amin Samsun Baharun, Norhayuza Mohamad, Ahmad Wan Abd Rahman \& Zuraini Ramli

To Link this Article: http://dx.doi.org/10.6007/IJARPED/v10-i1/8547

DOI:10.6007/IJARPED/v10-i1/8547

Received: 30 January 2021, Revised: 26 February 2021, Accepted: 10 March 2021

Published Online: 20 March 2021

In-Text Citation: (Baharun et al., 2021)

To Cite this Article: Baharun, M. N. A. S., Mohamad, N., Rahman, A. W. A., \& Ramli, Z. (2021). Investigating Mastery Level of Arabic Academic Vocabulary (AAV): A Study Among Malaysian Public Universities. International Journal of Academic Research in Progressive Education and Development, 10(1), 268-285.

Copyright: (C) 2021 The Author(s)

Published by Human Resource Management Academic Research Society (www.hrmars.com)

This article is published under the Creative Commons Attribution (CC BY 4.0) license. Anyone may reproduce, distribute, translate and create derivative works of this article (for both commercial and non-commercial purposes), subject to full attribution to the original publication and authors. The full terms of this license may be seen at: http://creativecommons.org/licences/by/4.0/legalcode

Vol. 10(1) 2021, Pg. 268 - 285

http://hrmars.com/index.php/pages/detail/IJARPED

JOURNAL HOMEPAGE

Full Terms \& Conditions of access and use can be found at http://hrmars.com/index.php/pages/detail/publication-ethics 


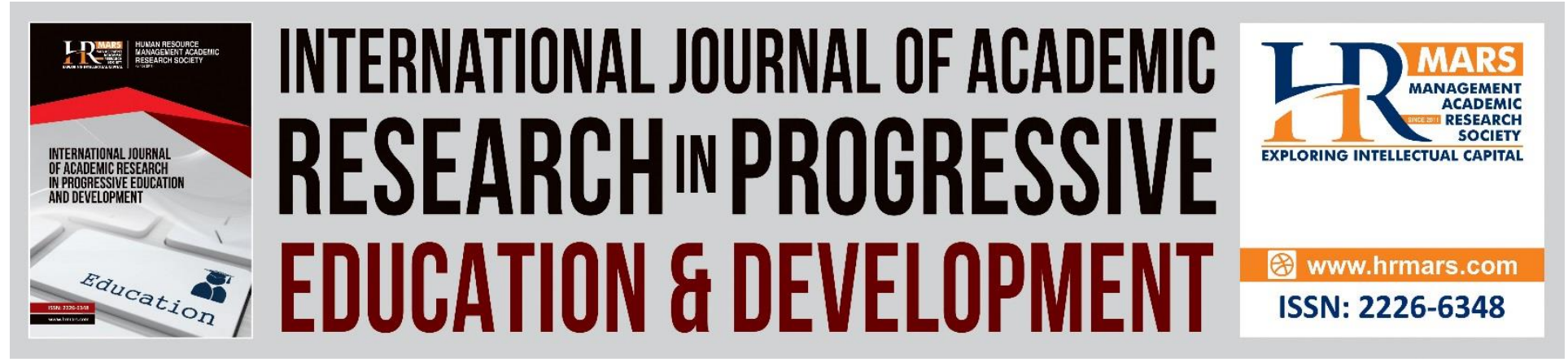

\title{
Investigating Mastery Level of Arabic Academic Vocabulary (AAV): A Study Among Malaysian Public Universities
}

\section{Mohamad Nor Amin Samsun Baharun, Norhayuza Mohamad, Ahmad Wan Abd Rahman \& Zuraini Ramli}

Akademi Pengajian Bahasa, Universiti Teknologi MARA, 40450 Shah Alam, Selangor, Malaysia Email: nor_amin@uitm.edu.my,norha571@uitm.edu.my, ahmad3677@uitm.edu.my, zuraini7475@gmail.com

\begin{abstract}
This quantitative study aims to identify the mastery level of Arabic academic vocabulary (AAV) as well as to identify differences in AAV mastery among students between six public universities in Malaysia using receptive and productive AAV test instruments. Researchers constructed AAV test questions based on the test format introduced by Schmitt (2000) with some modifications. A total number of 50 academic vocabularies were filtered from the Academic Word List (AWL) proposed by Davies and Gardner (2013) and was tested on 126 samples through purposive sampling. The data from the test were analysed descriptively using Microsoft Excel 2016 software and SPSS V25.0. The results of the study found that the overall mastery of AAV among Malaysian Public Universities (MPU) students is at a moderate level with a mean score of $66 \%$. In addition, there is a significant gap in the mean percentage in AAV mastery, namely IIUM which recorded the highest level (mean $=88 \%$ ), while UiTM has the lowest value (mean $=54 \%$ ). The results of the Kruskal-Wallis test showed that there was a significant difference in AAV mastery among students between the public universities. The post-hoc Bonferroni test also recorded the same which the value of $p=<0.05$.

Keywords: Arabic Academic Vocabulary (AAV), Academic Word List (AWL), Receptive and Productive AAV, Kruskal-Wallis Test, Post-hoc Bonferroni Test

Introduction

Arabic is the language of knowledge, civilization, and intelligence, widely used from ancient times to the present. Studies conducted earlier have proven that a lot of the uniqueness and specialty of the Arabic language is not available in other languages such as the aspects of vocabulary, syntactic methods and morphology found in this language (Muhammad, 2005). These days, learning Arabic in Malaysia has seen a rapid development. Arabic language learning is not limited
\end{abstract}


to just primary and secondary schools, but it is also offered in public and private institutions of higher learning. In fact, the Arabic language courses offered in institutions of higher learning have also started to evolve towards higher levels, including the masters and doctoral degrees.

However, in the meantime, the issues of teaching and learning Arabic still remain as a topic of discussion among teachers, researchers and curriculum developers. This is due to the fact where mastering the Arabic language is not an easy feat. Arabic language by itself comprises of foreign characters and spoken nuances which is clearly different from the typical Malay mother tongue. Arabic language typology is totally dissimilar from the local language, showcasing the vast differences in Arabic characters encompassing various aspects such as word construction, pronunciation, syntax, and others. Among the important aspects that are often discussed is the issue of student vocabulary mastery. Vocabulary is the most important measure to ensure that a student is said to have mastered Arabic. For high level students who follow the Arabic language academic program such as at the undergraduate, masters and doctoral levels, vocabulary mastery not only involves daily communication, but it also requires a higher level of vocabulary mastery or better known as academic vocabulary. This particular type of vocabulary is absolutely necessary in order to help students mastering the art of learning Arabic at a higher level, especially in reading activities as well as preparation of assignments and more.

\section{Problem Statement}

Student's achievement in vocabulary remains a topic of debate for teachers in schools and lecturers in universities. There are many studies portraying that the level of Arabic proficiency in students is still unsatisfactory. These include the problem of mastery for vocabulary forms and meanings (Mohamad, 2007), lexical errors (Mezah, 2009) as well as the problem of having a very limited vocabulary size (Husain \& Mohamad, 2020). For students at institutions of higher learning, it is essential to have the mastery of academic vocabulary in addition to ordinary vocabulary. This is due to the fact that almost all reading materials or scientific texts are filled extensively with academic vocabulary. Students need to master the vocabulary well in order to undergo the learning process effectively and subsequently be able to study successfully.

Based on the researchers' observation through their experience of teaching Arabic specialization at UiTM, it is found that most of the students faces multiple problems in learning the language due to low level of academic vocabulary. This causes students to have a disadvantage in their reading skills, understanding and analysing academic texts such as books, journals, scientific article papers, working papers and so on. Not only that, they also found it difficult to prepare a good academic writing and presentations when they are required to do academic projects.

It can be observed that studies on Arabic academic vocabulary have yet to attract the interest among researchers in Malaysia. Prior to this, most studies narrowed down their focus on daily vocabulary with less emphasis on academic vocabulary. Among the notable vocabulary studies in the field of Arabic language in Malaysia is a study relating to vocabulary size by Husain \& Mohamad (2020), Harun \& Ismail (2014). In addition, there are also studies related to the level of vocabulary mastery by Zaini (2015), Arabic vocabulary learning strategies (Harun, 2014), and 
lexical mistakes in Arabic language learning (Mezah, 2009). Up to this moment, studies in the field of Arabic academic vocabulary in Malaysia have not received due attention.

Acknowledging the importance of academic vocabulary mastery in an effort to mastering Arabic as a foreign language at the IPT level, and other factors such as the lack of available studies related to the Arabic academic vocabulary in Malaysia has prompted this group of researchers to conduct a study on this matter. Our study was conducted with the purpose of identifying the achievement of receptive and productive AAV mastery among students in six public universities in Malaysia. In addition, it also aimed to discern the extent of differences which exist between the achievement of receptive and productive tests among the students. It is hoped that through this study, researchers can further identify the level of AAV achievement of students in public universities covering both aspects of receptive and productive as well as understanding the issues related to it.

\section{Objective}

1. to identify the mastery level of Arabic academic vocabulary (AAV) between six public universities in Malaysia.

2. to identify differences in AAV mastery among students between six public universities in Malaysia.

\section{Vocabulary}

The majority of linguists have a very similar opinion with regard to the definition of 'vocabulary'. Hubbard (1983) has defined vocabulary as a powerful carrier of meaning (Heidari \& Pashayi, 2015). Whereas Diamond \& Gutlohn (2006) determine the definition of vocabulary as knowledge of a word and its meaning. This means that a good understanding and use of language will be difficult to achieve without a solid vocabulary aspect. Nation (2001) has determined the knowledge of vocabulary to the knowledge of a word in the form of speech of the word and the speech can be identified and understood in and out of context and not just a mere guess.

\section{Types of Vocabulary}

Based on previous studies on vocabulary, there are various types of vocabulary that have been listed by scholars. Thus, the researchers have selected two lists of vocabulary types that have been proposed by Nation and Dataworks Educational Research (2014). According to Nation (2001), urban vocabulary can be divided into four types as follows:

a) High-frequency words.

It is a General Service List of English Words (West Service, 1953) that has been listed by West's (1953) and has 2,000-word families.

b) Academic words.

It consists of more than 800-word families known as the University Word List (UWD) (Xue \& Nation, 1984; Nation 1990). The word list is a word that is not included in the general service list, but often appears in academic texts from various fields. This academic vocabulary is said to account for about 8.5 per cent of the total words in the academic text.

c) Technical words. 
Technical vocabulary is a word that is very closely related to the topic or subject in a text. The words in this category are different according to a field but usually the number is to be less than 1000 words for each field.

d) Low-frequency words.

It is a very rare group of words and covers only a small part of a text.

Apart from Nation (2001), Dataworks Educational Reseach which is California-based company has classified vocabulary types into three parts. The following is a list of vocabulary types by Dataworks Educational Research (2014):

a) Academic vocabulary (academic vocabulary).

Academic vocabulary is a vocabulary that is often found in the context of learning or academic texts. It can be found in texts from a variety of subjects and is not limited to a particular field.

b) Content vocabulary.

Content vocabulary is a vocabulary specific to a particular subject or field and it is rarely found outside of a particular field or subject.

c) Support vocabulary.

Support vocabulary is an excess of words that students need to know to understand a sentence or phrase used in a lesson.

Based on the types of vocabulary that have been classified by Nation and Dataworks Educational Research, researchers have chosen academic vocabulary as the focus of this study because it is said to be so significant with students, especially at the IPT level. This is clearly evidenced based on what Nation (2001) and Dataworks Educational Research have mentioned, that academic vocabulary is vocabulary that frequently appears in academic texts and is used by students in their learning process.

\section{Academic Vocabulary}

According to Yanti (2018), academic vocabulary is to be very important for the purpose of understanding the text in academic form. A person's lack of understanding regarding this vocabulary will affect the individual's academic literacy. In English, there are two lists of frequently used academic words namely University Word List (UWL) by Xue \& Nation (1984) and Academic Word List (AWL) by Coxhead (2000). Both lists are said to contain words that are not found in the general word list, but instead are often found in academic texts.

However, between these two lists, the Academic Word List (AWL) is seen as more recent compared to the University Word List. This is mainly because the University Word List (UWL) has a total of 836-word families and comprises only about 9.8 percent of the 3.5 million words from the academic text corpus. While the Academic Word List (AWL) has only 570-word families (word families) and only includes 10 percent of the words found in the academic text corpus. If the two list is to be examined, although the Academic Word List (AWL) has a smaller number of word families, it actually has a wider coverage in the academic text compared to the University Word List (UWL) (Zhou, 2010). 
Apart from that, the principle of word selection in the University Word List (UWL) is seen as inconsistent and has many weaknesses. The need for a new list of academic words has been stated by Coxhead (2000) in his article on Academic Word List (AWL) in the following passage:

"...as an amalgam of the four different studies, it (the UWL) lacked consistent selection principles and had many of the weaknesses of the prior work. The corpora on which the studies were based were small and did not contain a wide and balanced range of topics."

Zhou (2010) stated that the words in the Academic Word List (AWL) are selected considering the large corpus size in the written academic text. The words selected must meet the following criteria:

a) found in academic texts from four divisions of the academic faculty: Arts, Commerce, Law and Science.

b) appear more than 100 times in the entire corpus.

c) at least 10 times for each selected academic faculty division

d) not a word listed in the General Word List by Michael West.

Academic Word List (AWL) is commonly used as a reference for students preparing to learn English at the university level. It does not include content vocabulary for certain subjects where students may not avoid from learning. As a university lecturer, Coxhead is aware of the difficulties faced by students in mastering the vocabulary for the purpose of writing assignments. It also focuses on non-specific vocabulary where students from various disciplines need to master in order to produce writing in a structured and appropriate manner (Coxhead, 2000).

Based on the strength of the Academic Word List (AWL) developed by Coxhead, it was accepted as a new standard and has been adopted in English language education for over a decade (Gardner \& Davies, 2013). However, the study on the need for a new academic vocabulary list does not end at the Academic Word List by Coxhead alone. Dee Gardner and Mark Davies (2013) have reviewed the existing academic vocabulary list to further improve and produce a new academic vocabulary list (NAVL). Gardner \& Davies (2013) have set the following criteria in word selection to be listed in the New Academic Vocabulary List (NAVL):

a) the selected word is determined using the root word (lemma), not the word family.

b) the new academic vocabulary list must be based on a large English academic corpus, which represent and cover a wide range of important academic disciplines.

c) a list of new academic vocabulary must be obtained statistically from a large and balanced corpus size consisting of both academic and non-academic materials.

d) academic materials in the larger corpus as well as non-academic materials that is to be compared must represent contemporary English rather than material dated $20-100$ years ago.

e) a new list must be tested on both academic and non-academic corpus or derived from a corpus-derived list to determine its validity and reliability as a core list of academic words. 
In this study, the researchers have selected the academic vocabulary in the New Academic Vocabulary List (NAVL) developed by Gardner \& Davies (2013) to be used as a test construction instrument conducted on the selected sample.

\section{Receptive and Productive Vocabulary}

Most renowned researchers agree to divide vocabulary knowledge according to its scope of use in writing, reading, listening and speaking skills. Vocabulary knowledge can also be divided into productive and receptive vocabulary knowledge (Laufer, 1998; Laufer \& Paribakht, 1998; Henriksen, 1999; Nation, 2001; Read, 2000; Schmitt, 2014) in Maskor et al., (2016). However, Harmer (2001) has identified vocabulary knowledge as active vocabulary which students can use and pronounce orally. On the other hand, passive vocabulary is classified as words that students know through recognition but unable to pronounce or produced through writing (Maskor et al., 2016).

Receptive vocabulary are words used to identify and understand material when reading or listening. Vocabulary used productively in speech and writing activities is termed as productive vocabulary (Abdullah et.al 2012). According to Maskor et al., (2016) productive vocabulary is the process of expressing vocabulary knowledge in writing.

According to Zhou, 2010), one of the important dimensions in vocabulary knowledge is knowing both receptive vocabulary and productive vocabulary. Receptive vocabulary refers to a person's ability to understand a word when heard or seen, while productive vocabulary knowledge is a person's knowledge to produce a word when speaking or writing. In general, a word is known receptively at the beginning, and after a good learning and understanding process it can later be used productively. In conclusion, receptive vocabulary can be called passive and productive vocabulary is referred as active.

\section{An Overview on the Related Past Studies}

There are several studies done previously regarding academic vocabulary (KKA). These studies differ in terms of objectives and sampling. Some focus on the level of mastery of academic vocabulary, receptive vocabulary and productive vocabulary, strategies to learn academic vocabulary, the relationship between general vocabulary mastery with academic vocabulary and so on.

Among the studies related to the academic vocabulary of Arabic is a study by Makhoul (2017) which examines the development of receptive and productive Arabic academic vocabulary knowledge for native speakers at the secondary school level in Palestine. In this study, Makhoul has developed a list of Arabic academic vocabulary (AAV) by implementing the required academic word mapping that includes the informative texts contained in the textbook. A total of 600 samples from Arabic speakers who are students at the secondary level covering different areas of Israel (Palestine) consisting of three sub-groups of Arabs were selected namely, general Arab, Druze and Bedouin communities. Two academic vocabulary assessment tests consisting of receptive tests and productive tests were used as the instruments to achieve the objectives of 
the study. The results of the study found that there were significant differences between different Arab groups, namely it recorded the Bedouin group got the lowest score compared to the general Arab community and the Druze. While in terms of differences in academic vocabulary knowledge according to age level, there is an increase in receptive academic vocabulary knowledge at a higher age, but not on productive academic vocabulary knowledge. The results of the study also found that there is a gap in differences among students in terms of receptive and productive academic vocabulary.

In addition to Makhoul's study, Abdullah et al. (2012) have conducted a study on the mastery of English academic vocabulary among undergraduate students at MARA University of Technology (UiTM). A sample of 456 students from semesters one to six were selected from fifteen different undergraduate degree programs. The results of the study found that almost two-thirds of the sample of UiTM students failed to achieve the level of vocabulary mastery required to read the text efficiently and failed to infer the meaning of words that are rarely found.

Knežević, Županec \& Radulović (2020) have studied the effectiveness of the 'flipped classroom' approach for English language for academic purposes (EAP) in testing the effectiveness of understanding academic vocabulary. This approach is compared against the conventional teaching approach. This quantitative analysis states that the 'flipped classroom' approach indicates a higher effectiveness than the conventional approach. The findings also presented that the use of the 'flipped classroom' approach shows the best practical example in strengthening the understanding of academic vocabulary in English language courses for academic purposes (EAP).

The next study is from Huong (2018) titled "A survey study on academic vocabulary learning strategies by EFL university students". The objective of this study was to investigate English language vocabulary learning strategies among EFL university students. A total of 132 students from EFL University who took specialization in English translation and pedagogy were selected as the study sample. The results of the study found that students were more likely to use online dictionaries and other applications than to use cognitive strategies in academic vocabulary learning.

Malmstrom \& Gustafsson (2013) in their study "Master level writing in engineering and productive vocabulary: What does measuring academic vocabulary levels tell us?" has studied the level of mastery of productive vocabulary in writing for the master's degree specializing in various branches of engineering. Its main purpose is to measure the use of English academic vocabulary introduced by Coxhead (2000). It was tested on first and second year students studying Swedish Master of Science as well as international students. The findings show that second year students have mastered academic vocabulary in writing but unfortunately their performance is lower than first year students. Therefore, this study suggests that vocabulary development should be focused on vocabulary according to a particular discipline or field rather than focusing on general academic vocabulary (Malmstrom \& Gustafsson, 2013). 
Masrai (2018) conducted an academic vocabulary size test named as the academic vocabulary size test (AVST) which aims to measure the level of academic vocabulary knowledge of non-native English language speakers. The test contains a total of 114 English academic vocabulary developed by Coxhead (2001). The vocabulary is arranged according to frequency in the AWL list by column from left to right, i.e., the first column is the word that is most frequently repeated, and so on until the sixth column. The study results clearly shows that vocabulary learning from AWL is highly dependent on frequency effects.

Taghizadeh \& Khalili (2020) conducted study on general and academic vocabulary knowledge in academic reading comprehension. The study was trying to identify the relationship between general vocabulary and academic vocabulary with academic reading performance in English. The study sample was 120 undergraduate engineering students at the Iran University of Science and Technology. General and academic vocabulary tests were used as instruments for the study. The findings showed that there was an obvious correlation between academic and general vocabulary test scores and academic reading comprehension. The finding also revealed that the mastery of academic reading and academic vocabulary were found to be very low. Furthermore, the general vocabulary knowledge was the main contribution to academic reading comprehension. Based on the test scores, there is a close correlation between academic vocabulary mastery with general vocabulary.

Based on the studies found, mastery of academic vocabulary is seen to have gained the attention of researchers. However, the study of Arabic academic vocabulary has not been widely explored, especially in Malaysia. Most studies related to vocabulary are focusing on daily vocabulary and less focused on academic vocabulary.

\section{Methodology}

This study is a survey study that aims to identify and review the mastery level of AAV among Arabic language students in Malaysian public universities. It uses a descriptive analysis that will describe the level of mastery of public universities students in AAV. This study aims to identify the mastery level of AAV as well as to identify differences in AAV mastery among students between six public universities in Malaysia. It is a quantitative study that uses receptive and productive AAV test instruments. A total number of 126 samples from six public universities in Malaysia were selected as a study sample using purposive sampling. The samples consist of 43 male students and 83 female students who are from semester five to semester eight. They are specializing in Arabic at their respective universities. The following are the number of respondents according to the universities and their programme:

a) 21 respondents from Bachelor of Arabic Professional Comunication (Universiti Teknologi Mara (UiTM))

b) 21 respondents from Bachelor of Human Science (Arabic Language and Literature) (International Islamic University (IIUM))

c) 21 respondents from Bachelor of Arabic Language Education (Sultan Idris University of Education (UPSI)) 
Vol. 10, No. 1, 2021, E-ISSN: 2226-6348 @ 2021 HRMARS

d) 21 respondents from Bachelor of Arabic Language and Linguistics (University of Malaya (UM))

e) 21 respondents from Bachelor of Arts (Foreign Language) specialization in Arabic (Universiti Putra Malaysia (UPM))

f) 21 respondents of Bachelor of Islamic Studies (Arabic Studies and Islamic Civilization) (Universiti Kebangsaan Malaysia (UKM))

There are three instruments used for this study as follows:

\section{List of Academic Vocabulary}

In this study the researchers used $50 \mathrm{AAV}$ for receptive and productive vocabulary tests, which both tests use the same vocabulary. The selection of academic vocabulary is based on the Academic Vocabulary List (AVL) proposed by Davies and Gardner (2013). This 50-words represent $10 \%$ of the $500 \mathrm{AVL}$. The researchers selected 50 words from the list based on the common use of Arabic language students in Malaysia. All these words were later translated into Arabic and underwent a revision process. The words selected consisted of 38 nouns and 12 verbs.

The following is 50 -word list AAV tested in this study:

Table 1: List of AAV used in receptive vocabulary list test (RVLT) and productive vocabulary list test (PVLT).

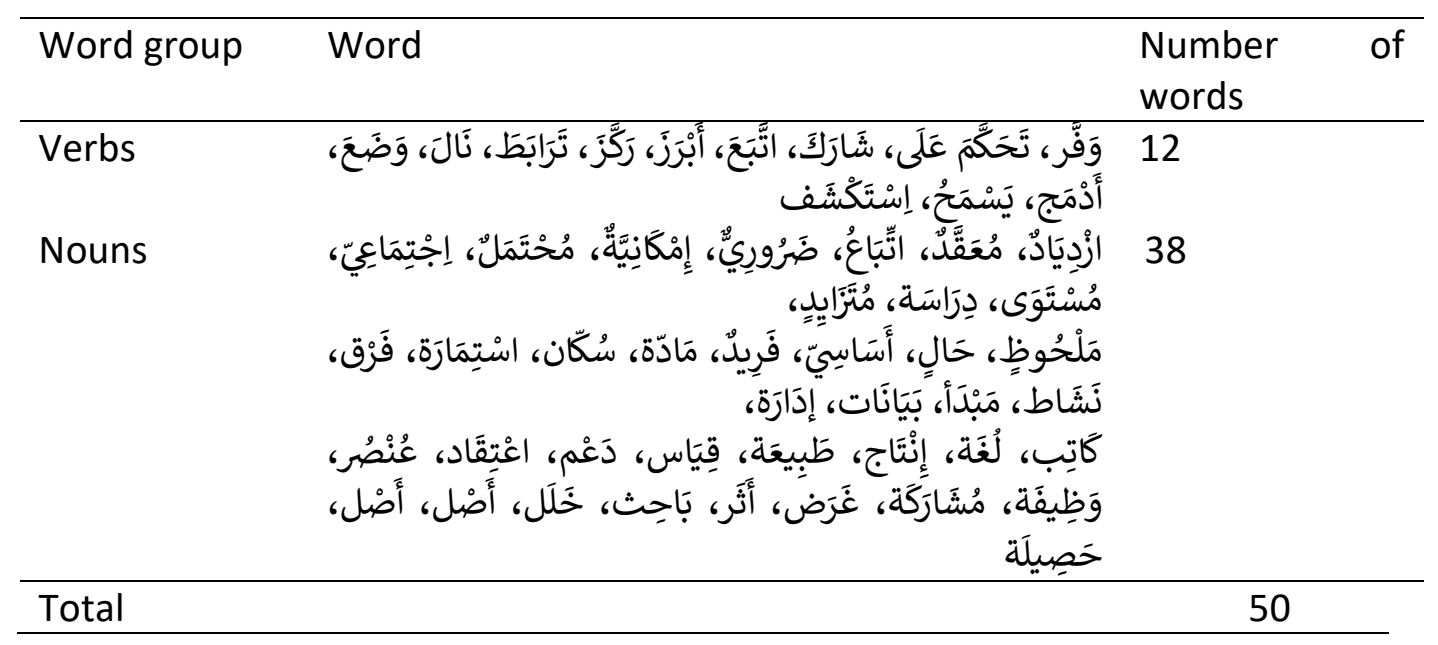

\section{Receptive AAV Test}

This test aims at measuring the level of AAV receptive mastery of respondents. The questions in this section are formed by combining 3 question items with 6 multiple choices. This test is formatted by matching the definition or description of the meaning of the word. This question was adapted from the test developed by Paul Nation in 1983 and 1990 and redeveloped by Schmitt (2000). It aims to measure students' academic receptive vocabulary knowledge. Based on the test the respondents were asked to match the definition and meaning of the words listed 
INTERNATIONAL JOURNAL OF ACADEMIC RESEARCH IN PROGRESSIVE EDUCATION AND

DEVELOPMENT

Vol. 10, No. 1, 2021, E-ISSN: 2226-6348 @ 2021 HRMARS

with the item. Each correct answer is given one mark. Thus, the full marks for this section are 50 marks representing 50 questions.

The following is an example of the test suggested by Schmitt (2000):

1. acess

2. gender

3. implementation male or female

4. license study of mind

5. orientation

6. psychology entrance or way in

The following is an example of Arabic receptive question used in this test. The form of question presentation has been slightly modified to facilitate students' understanding of the requirements of the question:

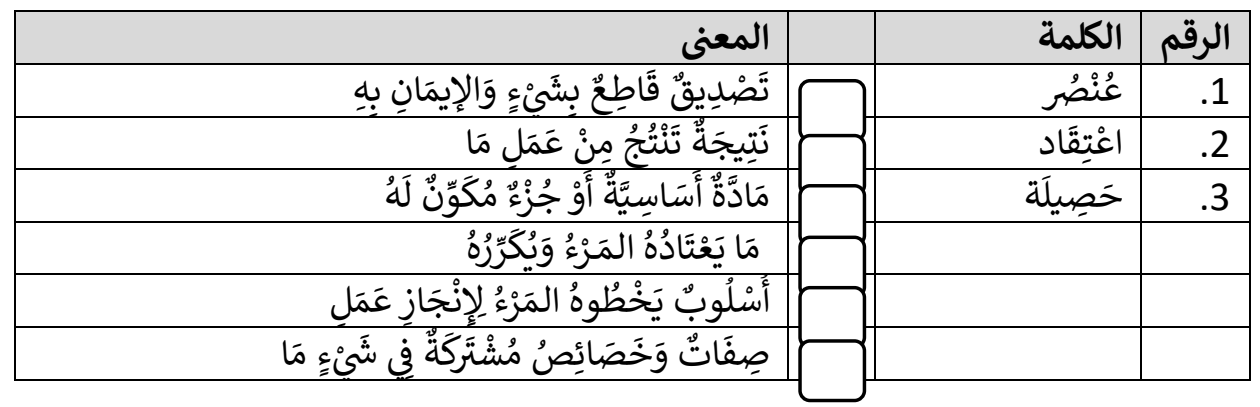

Productive AAV Test

This test aims at measuring the acquisition level of productive AAV of respondents. Students were asked to fill in the blanks assisted by a few letters at the beginning of the word as a clue. The question has fully followed the format developed by Paul Nation in 1983 and 1990 and redeveloped by Schmitt, Schmitt and Clapham (2001). The aim is to measure the students' academic vocabulary knowledge. Each correct answer is given one mark. Thus, the full marks for this section are 50 marks representing 50 questions. The following is an example of the PVLT test proposed by Schmitt (2000):

The ar of his office is 25 square meters.

They ins all products before sending them out to stores.

The following is an example of Arabic productive question in the receptive test:

\begin{tabular}{|c|c|}
\hline المعنى & 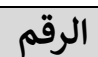 \\
\hline 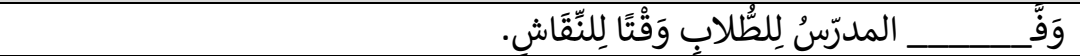 & .1 \\
\hline ــ الطلابُ مَهَارَتَهُمْ في الكَلامِ فِي مُسابقَةِ الخَطَابَةِ. & .2 \\
\hline ـــ المدرّسن فِي تَدْرِيسِهِ على الطَّلابِ المُبْتَدِئِينَ. & .3 \\
\hline 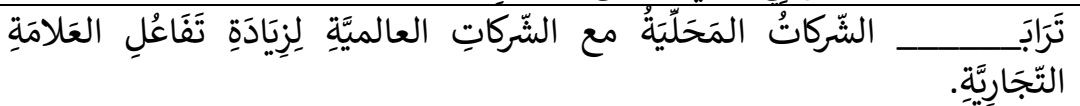 & .4 \\
\hline 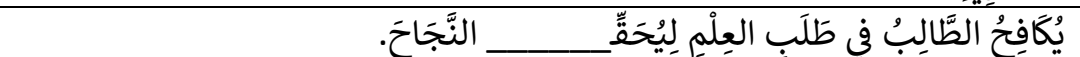 & .5 \\
\hline
\end{tabular}


The data collection process was implemented during the lecture session to prevent the dropout of respondents. Respondents were informed in advance by the lecturer about the implementation of the tests which has been partly handled by the researchers and by the Arabic language lecturers at the universities. This test was conducted within the time limit of an hour and thirty minutes. The researchers placed a time interval between receptive and productive tests. The receptive test was performed first, and the productive test was conducted two weeks later. This is to ensure that students are not influenced by receptive test answers when they answer productive tests due to the same vocabulary used in both tests.

Students answers were checked and marked by the researchers. All questions have a value of 1 mark; 50 marks for receptive questions and 50 marks for productive questions to form 100 marks which is full marks. In terms of scoring receptive questions, the marks are according to the correct choice of answers, while the grading of productive questions is based on the words answered by students. The researchers only determine 1 mark for the correct answer and 0 marks for the false.

The data collected from 126 students were analyzed using Microsoft Excell 2016 to obtain the percentage and mean value. Researchers also used SPSS v25 which includes 3 statistical tests. The Shapiro-Wilk test was firstly used to test the assumption of data normality. It was then followed by the Kruskal-Wallis test to identify significant difference in AAV mastery among students between MPUs. Furthermore, the post-hoc Bonferroni test was used to see significant differences in AAV mastery between universities in pairs.

\section{Result and Discussion}

After conducting tests on respondents in six MPUs, the first objective that is to identify the level of mastery of AAV among students has been successfully obtained. Table 2 explains the details.

Table 2: Percentage mean of AAV tests for each public university

\begin{tabular}{lllr}
\hline \multicolumn{2}{c}{ Percentage (\%) } & & \\
\hline University & Receptive & Productive & Mean \\
UPM & 44 & 74 & $\mathbf{5 9}$ \\
UiTM & 51 & 57 & $\mathbf{5 4}$ \\
UPSI & 49 & 71 & $\mathbf{6 0}$ \\
UM & 73 & 80 & $\mathbf{7 6}$ \\
UKM & 45 & 67 & $\mathbf{5 6}$ \\
UIAM & 81 & 94 & $\mathbf{8 8}$ \\
\hline TOTAL & $\mathbf{5 7}$ & $\mathbf{7 4}$ & $\mathbf{6 6}$ \\
\hline
\end{tabular}

Based on the table 2, the level of AAV mastery in all public institutions of higher learning shows that the mean score achievement is $66 \%$, which is categorized as moderate based on the UiTM results table issued by UiTM diploma and bachelor academic rules (amended 2017). 
To achieve the second objective in identifying differences in AAV mastery among students between the MPUs, table 2 is also referred. It was found that there were differences in AAV mastery among students. Based on the mean obtained for each MPUs, it can be observed that IIUM obtained the highest mastery (88\%), followed by UM (76\%), UPSI (60\%), UPM (59\%), UKM (56\%) and UiTM ranked last (54\%).

Hypothesis testing was carried out using the Shapiro-Wilk test in order to identify the significant differences in AAV mastery among students between MPUs. The null hypothesis is that there is no difference in AAV mastery among students between MPUs. The distribution of data was tested to determine normality in the data. If the distribution of data is normal, then the parametric test involving one-way ANOVA test may be used for testing the hypothesis. The assumption of normality using the Shapiro-Wilk test is carried out on each dependent variable according to the university group. The findings of the Shapiro-Wilk test on each group of AAV mastery variables showed that one group had a $p$ value below $0.05(p=<0.05)$, thus proving that the assumption of normality was not met. Therefore, the proposed analysis is to use non-parametric test, namely the Kruskal-Wallis test. The following table is the results of the Shapiro-Wilk test:

Table 3: Shapiro-Wilk test.

\begin{tabular}{cllll}
\hline University & Statistic & dk & Sig. \\
\hline UPM & 0.948 & $! 1$ & 0.313 \\
\hline UiTM & 0.992 & $! 1$ & 0.999 \\
\hline UPSI & 0.930 & $! 1$ & 0.138 \\
\hline UM & 0.884 & $! 1$ & $0.017^{*}$ \\
\hline UKM & 0.959 & $! 1$ & 0.496 \\
\hline UIAM & 0.970 & !1 & 0.737 \\
\hline \multicolumn{5}{c}{ *value of $p=<0.05$}
\end{tabular}

The results of the Kruskal-Wallis test show that there is a significant difference in AAV mastery among students between six public universities, $(5)=61.699, p<0.001$. Further analysis through the post-hoc Bonferroni test showed that there were significant differences in AAV mastery between groups of UiTM and UM students $(p<0.001)$, UiTM and IIUM ( $p<0.001)$, UKM and UM students ( $p=0.002)$, UKM and IIUM $(p<0.001)$, UPM and UM ( $p=0.019)$, UPM and IIUM ( $p$ $<0.001)$ and UPSI and IIUM ( $p<0.001)$. These results indicate that the null hypothesis is rejected. The table below shows the results of the Kruskal-Wallis test: 
INTERNATIONAL JOURNAL OF ACADEMIC RESEARCH IN PROGRESSIVE EDUCATION AND

DEVELOPMENT

Vol. 10, No. 1, 2021, E-ISSN: 2226-6348 @ 2021 HRMARS

Table 4: Kruskal-Wallis test

\begin{tabular}{llllll}
\hline University & $\mathbf{N}$ & $\begin{array}{l}\text { Mean } \\
\text { rank }\end{array}$ & $x^{2}$ & $\mathbf{d k}$ & Sig. \\
\hline UPM & 21 & 49.98 & 61.699 & 5 & $<$ \\
UiTM & 21 & 38.19 & & & 0.001 \\
UPSI & 21 & 55.12 & & & \\
UM & 21 & 86.29 & & & \\
UKM & 21 & 42.52 & & & \\
IIUM & 21 & 108.90 & & & \\
\hline
\end{tabular}

\section{Conclusion}

The findings of this study show that AAV mastery among public universities students in Malaysia is at a moderate level. This can be seen from the mean value of achievement test for all public universities that recorded a mean score of $66 \%$ (refer to table 2). Based on the respondents' feedback, it was found that most students have experience learning Arabic between 12 to 14 years. However, the level of mastery of AAV is still at moderate level. Researchers perceive that although the respondents have been learning Arabic for a long time, it is probably due to the lack of effective use of AAV in writing and speaking activities.

This finding is in line with the study of Harun \& Ismail (2014) who found that students at the preuniversity level mostly only mastered within 700 words only, while the Arabic language syllabus targets mastery of a total vocabulary of 3000 at the upper secondary level. It can be concluded that the vocabulary mastered by students is still far from being able to achieve the objective of the syllabus. While students' general vocabulary of Arabic is still at a weak level, academic vocabulary mastery has proven to be more difficult to achieve. This is also in line with the findings of the study of Kaseh et.al. (2011) who said that the Arabic language proficiency of university students at the postgraduate level is at a weak level even though they have studied Arabic at all levels through the years including undergraduate, pre-graduate and secondary levels.

Ab. Halim (2007); Sueraya et al. (2010) confirmed the same thing that the mastery of Arabic among public university graduates who are majoring in Arabic still do not achieve a good level of proficiency due to lack of vocabulary (Anuar et al., 2014). The findings of this study as well as other studies related to the vocabulary have given a signal on the Arabic general vocabulary and AAV particularly is still at an unsatisfactory level, thus it requires more effort from certain parties to address these issues of weaknesses.

To identify the differences in AAV mastery among students, the findings of the study show that there is a gap in differences in AAV mastery between the universities. This can be seen in the table 2 which shows that IIUM recorded the highest level of AAV mastery with a mean score of $88 \%$, while UiTM recorded the lowest level with a mean score of $54 \%$. Meanwhile, UM ranked second highest after IIUM with a mean score of $76 \%$, followed by UPSI $60 \%$, UPM $59 \%$ and UKM ranked second lowest at $56 \%$. The results of statistical tests conducted through the Kruskal-Wallis test show that there is a significant difference in AAV mastery among students between six public universities. Meanwhile, the results of the analysis through the post-hoc Bonferroni test also confirmed that there is a significant difference in mastery of AAV with a value of $p=<0.05$. The 
Vol. 10, No. 1, 2021, E-ISSN: 2226-6348 @ 2021 HRMARS

researchers perceive that the significant gap between public universities and the problem of AAV mastery encountered is due to the mixed and interrelated factors as follows:

\section{a) Arabic Language Learning Background}

For IIUM students that achieved the highest mastery in AAV among public universities, they usually study at the foundation center for two years prior to furthering their studies to the undergraduate level at the main campus. While at the foundation level, they are required to take Arabic language courses as a prerequisite for graduation. The researchers see that the learning of Arabic language subjects and learning environment at the IIUM basic level indirectly gives early exposure to IIUM respondents about Arabic. Nevertheless, in UITM for example, which was seen to have the lowest achievement, students who are studying bachelor's degree are not exposed to the basic program as in IIUM. The low mastery of AAV in UiTM is seen as UITM is among the youngest universities that offers Arabic language study programs compared to other public universities, especially IIUM, which is more matured in terms of curriculum and has undergone several reviews. Meanwhile, UiTM respondents who follow the first study plan since offered in 2013 di not undergo curriculum review.

\section{b) Learning environment}

The researchers believe that the learning environment also causes a gap in difference in AAV mastery among MPUs students. For example in IIUM, there are more lecturers and students from Arabs compared to other public universities. This situation is seen to create a learning environment that helps students to master Arabic better through continuous communication and practice, so it contributes to AAV's mastery. On the other hand, the environment in UiTM there are no Arab lecturers and classmates from Arab countries.

\section{c) Student motivation}

The researchers perceive that the emphasis on vocabulary teaching through language skills subjects in public universities contributes to the mastery of AAV. Apart from that, the type of Arabic language study program offered at each universities is very important as well to determine the level of mastery of AAV among students. In UM, for instance, emphasizes on applying language and linguistic studies, UPM and IIUM emphasize on the knowledge of Arabic literature, UPSI presents educational Arabic language studies, while UiTM emphasizes on language studies for professional communication. The various types of language study programs through its courses also seems to contribute to the differences in the level of mastery of AAV among MPUs students. The researchers also perceive that the selection of courses that does not meet the tendency of students causes their interest and motivation towards Arabic language courses to be at an unsatisfactory level. This can be seen in terms of course selection when submitting an application for admission to the public university in the online system. Based on the researcher's observation, there are a number of students who are selected to study Arabic language program at the public university are not from the main choice when filling out the Student Admission Unit (Unit Pengambilan Universiti (UPU)) form. 
Vol. 10, No. 1, 2021, E-ISSN: 2226-6348 @ 2021 HRMARS

\section{Theoretical and Contextual Contribution}

The results from this study found that Arabic academic vocabulary (AAV) proficiency among students is at a moderate level despite having gone through a long period of learning. This matter should be taken into consideration by all parties involved in the study to take initiatives in enriching the students' academic vocabulary. In addition, the significant mastery differences between the six universities urge the parties involved, especially the lecturers to motivate their students to master the vocabularies. This is to ensure that the academic materials studied can be understood and translated well according to the academic language mould.

\section{Acknowledgements}

This study is conducted under a registered research grant: (600-IRMI/Dana KCM 5/3/ LESTARI $(181 / 2017)$

\section{References}

Abdullah, N. A., Muhammad, A. M., Abidin, S. A. Z., Manan, N. A. (2012). Mastery of academic English vocabulary among undergraduate students in a public university in Malaysia. Research Management Institute.

Anuar, M. S., Muhamad, I., Salihin, W., Ismail, M. N., \& Seman, Z., (2014). Interaksi penguasaan bahasa arab - strategi dalam proses kefahaman teks kesusasteraan arab: Implikasinya terhadap pengajaran guru. Prosiding Seminar Pengajaran \& Pembelajaran Bahasa Arab 2014. Fakulti Pengajian Islam, UKM \& Fakulti Kontemporari Islam, UniSZA.

Muhammad, A. (2005). Beberapa aspek keunikan dan keistimewaan bahasa arab sebagai bahasa al-quran. Sains Humanika, 42(1), 61-76. doi: https://doi.org/10.11113/sh.v42n1.350

Baharudin, H., Ismail, Z., Asmawi, A., \& Baharuddin, N. (2014). TAV of Arabic language measurement. Mediterranean Journal of Social Sciences, 5(20), 2402. doi: 10.5901/mjss.2014.v5n20p2402.

Baharudin, H., \& Ismail, Z. (2014). Aspek saiz dalam pembelajaran kosa kata bahasa arab. Prosiding Wacana Islam Kebangsaaan siri ke-10. Fakulti Pendidikan UKM, Jabatan Hal Ehwal Agama Islam Negeri Sabah.

Baharudin, H., \& Ismail, Z. (2014). Vocabulary learning strategies and Arabic vocabulary size among pre-university students in Malaysia. International Education Studies, 7(13), 219226. doi:10.5539/ies.v7n13p219.

Coxhead, A. (2000). A new academic word list. TESOL Quarterly, 34(2), 213-238. doi:10.2307/3587951

Cunningham, J. W., \& Moore, D. W. (1993). The Contribution of Understanding Academic Vocabulary to Answering Comprehension Questions. Journal of Reading Behavior, 25(2), 171-180. doi:10.1080/10862969309547809.

Data Works Educational Research. (2014). Retrieved from Vocabulary Development Part 1: Types of Vocabulary. Retrieved from https://dataworks-ed.com/blog/2014/07/vocabularydevelopment-part-1-types-of-vocabulary.

Diamond, L., \& Gutlohn, L. (2006). Teaching vocabulary. Retrieved from http://www.readingrockets.org/article/9943 
INTERNATIONAL JOURNAL OF ACADEMIC RESEARCH IN PROGRESSIVE EDUCATION AND

DEVELOPMENT

Vol. 10, No. 1, 2021, E-ISSN: $2226-6348$ @ 2021 HRMARS

Ferreira, L. H. F. (2007). How to teach vocabulary effectively: An analysis of the course book eyes and spies (Bachelor's thesis). http://portaldoconhecimento.gov.cv/ bitstream/10961/2431/1/last version.pdf

Gardner, D., \& Davies, M. (2013). A new academic vocabulary list. Oxford University Press. Applied Linguistics, 35(3), 305-327. doi:10.1093/applin/amt015

Malmstrom, H., \& Gustafsson, M. (2013). Mastery level writing in engineering and productive vocabulary - What does measuring academic vocabulary levels tell us?. 123-238. Stochholm Studies in English. Retrieved from

https://www.researchgate.net/publication/307607361, Master Level Writing in Engineering and Productive Vocabulary: What does Measuring Academic Vocabulary Tell us?

Harun, B. (2014). Strategi pembelajaran kosa kata bahasa Arab pelajar sekolah menengah agama di Malaysia. Phd Thesis. University of Malaya.

Harun, B., \& Ismail, Z. (2014). Aspek saiz dalam pembelajaran kosa kata bahasa Arab. Wacana Pendidikan Islam Peringkat Kebangsan Siri Ke-10 (WPI10), Fakulti Pendidikan, Universiti Kebangsan Malaysia \& Majlis Ugama Islam Sabah.

Hashim, H., Bakar, K. A., \& Ahmad, M. (2020). Penguasaan kosa kata bahasa arab menerusi pengetahuan makna dan penggunaannya. MALIM: Jurnal Pengajian Umum Asia Tenggara, 21(2020): 157-171. doi:10.17576/malim-2020-2101-13.

Heidari, A., \& Pashayi, J. (2015). The Effect of Advertisements on Improving Turkish Young EFL Learners' L2 Vocabulary Learning. Journal of Applied Linguistics and Language Research, 2(7), 179-186. https://www.jallr.com/index.php/JALLR/article/view/171.

Huong, L. P. H. (2018). A survey study on academic vocabulary learning strategies by EFL university Students. Journal of Language Teaching and Research, 9(5), 1009-1016. doi: http://dx.doi.org/10.17507/jltr.0905.15

Husain, N. H., \& Mohamad, N. (2020). Saiz kosa kata bahasa Arab dalam kalangan pelajar ijazah sarjana muda bahasa arab komunikasi professional, UiTM. International Journal of Modern Languages and Applied Linguistics, 4(2), 38-62. doi: 10.24191/ijmal.v4i2.8722.

Jamalzadeh, M., \& Chalak, A. (2019). A corpus-based study of academic vocabulary in physiotherapy research articles. Language Teaching Research Quarterly, 9, 69-82. doi: 10.32038/Itrq.2018.09.06.

Knežević, L., Županec, V., \& Radulović, B. (2020). Flipping the classroom to enhance academic vocabulary learning in an English for academic purposes (EAP) course. Original Research. doi.org/10.1177/2158244020957052. doi: 10.1177/2158244020957052 journals.sagepub.com/home/sgo

Makhoul, B. (2017). Investigating Arabic academic vocabulary knowledge among middle school pupils: receptive versus productive knowledge. Journal of Psycholinguistic Research, (46), 1053-1065. doi:10.1007/s10936-017-9479-x.

Maskor, Z. M., \& Baharudin, H. (2016). Receptive vocabulary knowledge or productive vocabulary knowledge in writing skill, which one important?. International Journal of Academic Research in Business and Social Sciences, 6(11), 261-271. doi:10.6007/IJARBSS/v6i11/2395. 
INTERNATIONAL JOURNAL OF ACADEMIC RESEARCH IN PROGRESSIVE EDUCATION AND

DEVELOPMENT

Vol. 10, No. 1, 2021, E-ISSN: 2226-6348 @ 2021 HRMARS

Maskor, Z. M., Baharudin, H., \& Lubis, M. A. (2016). Pengetahuan kosa kata produktif dalam kemahiran menulis. Prosiding Wacana Pendidikan Islam siri ke 11, 857-866. UKM, JAKIM. https://www.researchgate.net/publication/311668345.

Masrai, A. (2018). Academic vocabulary size test (AVST).

https://www.researchgate.net/publication/322317600_Academic_vocabulary_size_test AVST

Mezah, C. R. (2009). Kesilapan leksikal dalam pembelajaran bahasa Arab. Serdang: UPM Press.

Mohamad, N. (2007). Penggunaan strategi pemetaan semantik dalam pengajaran kosa kata bahasa Arab. Phd Thesis. Kuala Lumpur: Universiti Malaya.

Nassaji, H. (2015). Qualitative and descriptive research: Data type versus data analysis. Language Teaching Research, 19(2), 129-132. doi:10.1177/1362168815572747

Nation, I. (2001). Learning vocabulary in another language. United Kingdom: Cambridge University Press.

Schmitt, N. (2000). Vocabulary in language teaching. United Kingdom: Cambridge University Press.

Schmitt, N., Schmitt, D., \& Clapham, C. (2001). Developing and exploring the behaviour of two new versions of the vocabularylevels Test. Language Testing, 18(1), 55-88. doi:10.1177/026553220101800103.

Shamsuri, S. (2004). Research methods for the social sciences: Made simple. Klang: DSS Publishing Entreprise.

Taghizadeh, M., \& Khalili, M. (2020). Predictive role of general and academic vocabulary knowledge in academic reading comprehension, $7^{\text {th }}$ National Congress on Applied Research Language Studies, 1-6.

Valipouri, L., \& Nassaji, H. (2013). A corpus-based study of academic vocabulary in chemistry research articles. Journal of English for Academic Purposes, 12(4), 248-263. doi:10.1016/j.jeap.2013.07.001.

Webb, S. (2005). Receptive and productive vocabulary learning: the effects of reading and writing on word knowledge. Studies in Second Language Acquisition, 27(1), 33-52. http://www.jstor.org/stable/44486803.

Yanti, C. H. (2018). Academic vocabulary mastery and perception for efl students of Universitas Bina Darma. Holistics Journal, 10(19), 1-8. Retrieved from https://www.jurnal.polsri.ac.id/index.php/holistic/article/view/971

Zaini, A. R. (2015). Penguasaan kosa kata bahasa arab dalam kalangan pelajar melayu di peringkat kolej universiti. Phd Thesis. Kuala Lumpur: Universiti Malaya.

Zhou, S. (2010). Comparing receptive and productive academic vocabulary knowledge of Chinese EFL learners. Asian Social Science, 6(10), 14-19. Retrieved from http://citeseerx.ist.psu.edu/viewdoc/download?doi=10.1.1.673.2803\&rep=rep1\&type= pdf. 